\title{
Factors Influencing Development of Perspective Taking Ability among Late Adolescence
}

\author{
Eko Darminto, Hadiwarsito Wiryosutomo, Retno Tri Hariastuti \\ Universitas Negeri Surabaya \\ Surabaya, Indonesia \\ ekodarminto@unesa.ac.id
}

\begin{abstract}
The objective of this study was to examine four internal variables which theoretically influenced on the development of late adolescence perspective taking ability (PT), i.e.: cognitive abilities (CA), social motivation (CM), emotional regulation (ER), and interpersonal skills (IS). The samples of the study were 148 late adolescence who were randomly selected from four kinds of public high school in Surabaya i.e: two public senior high schools, one public vocational school, and one public theology school. Data of PT, CM, ER, and IS were measured by inventory/scale with the alpha Cronbach coefficient respectively by $0.905,0.871,0.911$, and 0.752 while the $C A$ was measured by standard cognitive ability test. The data were analized statistically using linier multipe regression formulas. This study produced three main findings. First, four investigated variables significantly influence simultaneously to the PT with determination coefficient is 0.528 or $52.8 \%$, and $47.2 \%$ is explained by other variables. Second, the finding proves that from four variables investigated, only IS contributed not significant. Third, CM gives the highest influence on the PT with a contribution of 0.492 while the contribution of $C A$ is 0.267 ; ER is 0, 241; IS is 0.012 .
\end{abstract}

Keywords-perspective taking, cognitive ability, social motivation, emotional regulation, interpersonal communication skills.

\section{INTRODUCTION}

Perspective taking (PT) is an interesting psychological construct to be studied in the field of school guidance and counseling, especially because it affects the student's phisycall, cognitive, and social development [1]. PT is a fundamental social competence in social interaction [2][3][4] and therefore it can facilitate individuals to achieve success in various areas of life [5]. Individuals with high PT tend to be more able to handle conflict, have more social interest, and are more successfull in achieving their goals. Many research have reported that individuals with high PT are more altruis and can handle various forms of negative social behaviors such as stereotypes, impulsivity, prejudice, and aggressiveness [6][7][8][9]. Other studies have shown that PT can encourage successful learning of learners $[10][11][12][13][14]$ to become effective leaders and can adapt effectively to the modern, plural, and global community [15][16][17].
PT is defined simply as a cognitive ability to see a situation based on the viewpoint of others $[18][2][19][7][14][9][20]$. Conceptually, PT refers to the ability to understand and appreciate other people's point of view, both cognitively and affectively and then can act appropriately in according with the viewpoint of others $[21][13][14][22][23]$. The viewpoint of others is refers to how people think, feels, and will taking and act when they face or experience a situastion [24][25][26]. PT is not an innate ability but it can be developed through guidance or environmental intervention [10][9][27] and each individual has the same potential to develop perspective taking but results may vary according to a number of factors [28]. Individuals achieve PT abiities at a mature level when they have reached the late adolescence periods [27].

Although many scholars have asserted the influence of PT on individual development and success, unfortunately many schools do not have this program, at least in Indonesian. School guidance and counseling that organizes this program will be more effective in encouraging student development. In particular, this program can be used by school counselors as a strategy to: (1) improve academic success; (2) prevent negative social behavior such as aggression (acts of violence) and oppression; and (3) encourage future career success.

Intervention programs to encourage individual development are done by modifying the factors that affect the development [29]. Therefore this research is based on the premise that in order to effectively design an effectively program of development PT, it must first be understood of the important factors that influence it. As stated by Gehlbach [14], to encourage the development of PT, it must be well understood about the process underlying the development of PT, that is the relation of PT to a number of factors.

This study aimed to find the factors which played an important role in influencing the development of PT to which just focused on personal factors which were relatively modifiable through guidance and counseling interventions. This study based on integration the PT model of Gehlbach [24], Parker, Atkins, \& Axtell [25], and $\mathrm{Ku}$, Wang, \& Galinsky [26] as a conceptual framework. Based on the 
framework, this study examines four factors of personal factors which assume to play a significant role in influencing individual PT, they are: cognitive ability (CA), social motivation (SM), emotional regulation (ER), and interpersonal skills (IS). This research proposed three following hypothesys: (1) CA, SM, ER, and IS may affect
PT jointly (combinative) and individually (partially); (2) CA, SM, ER, and IS interacts with each other and influences PT; (3) CA, SM, ER, and IS may affect the perspective taking either directly or indirectly. The functional relationship between these variables is illustrated in the conceptual model in chart 1 below.

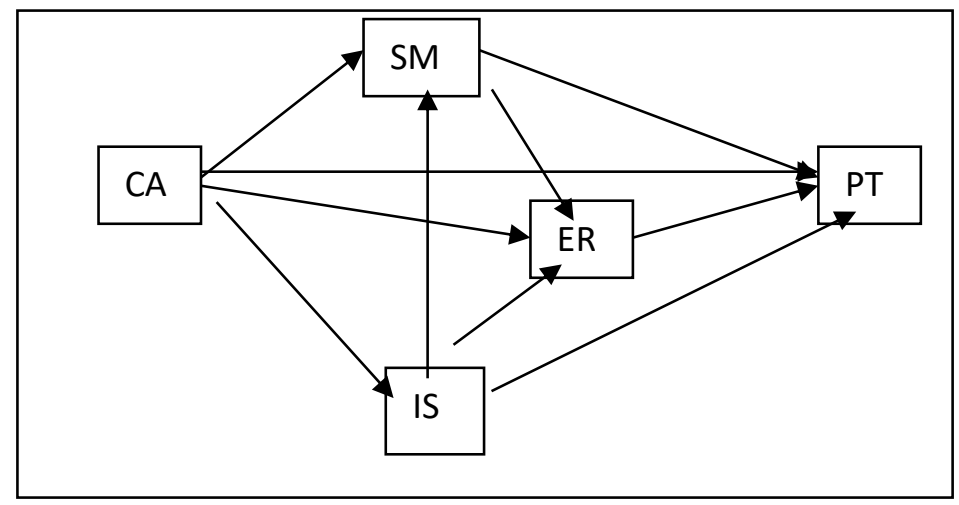

Chart 1. Conceptual model of the relationship between the variables of perspective taking (PT) with cognitive ability (CA), social motivation (SM), emotional control (ER), and interpersonal skills (IS)

\section{METHOD}

Approach and design. This research was conducted by Causal Relationship Study design. This design is a quantitative approach which used to explain the functional relationship and the level of relationship between variables which are studied [30].

Table 1. The sampels and the compositions

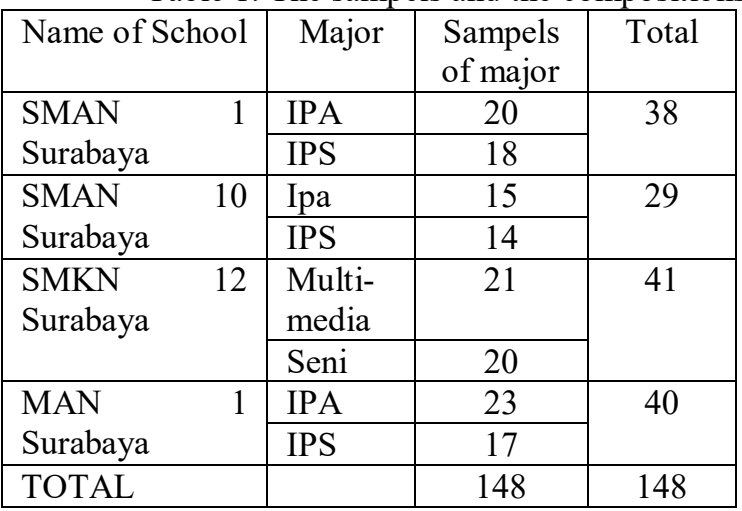

Research instrument. Data of CA was measured through standardized cognitive ability tests, i.e. the Differential Aptitude Test (DAT) on sub tests of verbal, abstract, and numerical abilities while data of SM, ER, ER, IS, and PT were measured through inventory/scala. This inventory was developed by the researcher and achieved sufficient degree of reliability through exploratory factor analysis. Each instrument had a Cronbach Alpha reliability value of 0.905 for SM scale; 0.752 for PT scale; 0.871 for the ER scale, and 0.911 for the IS scale.
Population and sample. The population of this study were students who reached the late adolescence period, i.e. between 15 and 20 years old. The samples of the study were 148 students who selected randomly from all students of the following four high schools in Surabaya, namely SMAN 2, SMAN 10, SMKN 12, and MAN 1. The samples and the compositions are illustrated in Table 1 below.

Data analysis. Data of this research were analyzed quantitatively through statistical techniques. The statistical formula used was multiple regression with the least squares approach/technique known as OLS (Ordinary Least Squares).

\section{RESULTS AND DISCUSSION}

Before the data analyzed, it is necessary to test the assumptions to meet the parametric requirements. There are four assumptions tested: linearity, multicollinear, heteroscedasticity, and normality. Assumption test is performed by making estimation (appraisal) to regression coefficient. Estimation is done by using the least squares method (ordinary least square). The linearity assumption test results give the data that the linearity requirements of all data have been fulfilled on all paths in the hypothetical model, no multicollinearity in the research data, no heteroscedasticity on residual values, and data distribution in all data tend to be normal.

Results of analysis. Results of multiple regression analysis using SPSS version 17 obtain the output as presented in table 2 s.d. 4 below. 
Tabel 2. Summary of regression equation

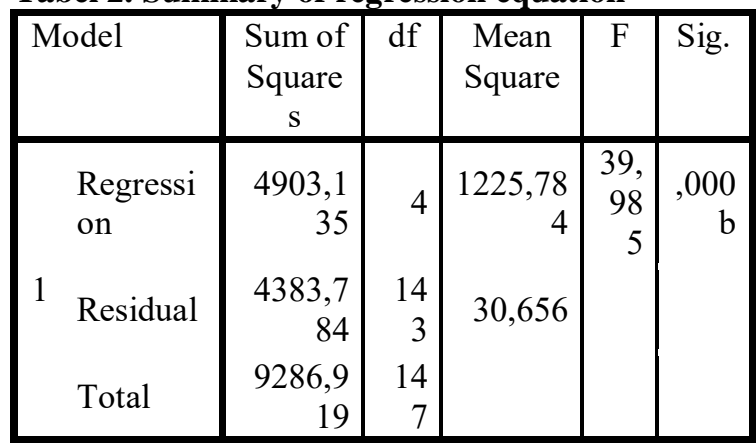

Table 3. Model Summary of determination coefficient

\begin{tabular}{|l|l|r|r|c|}
\hline $\begin{array}{l}\text { M } \\
\text { od } \\
\text { el }\end{array}$ & $\mathrm{R}$ & $\begin{array}{c}\mathrm{R} \\
\text { Square }\end{array}$ & $\begin{array}{c}\text { Adjusted } \\
\text { R Square }\end{array}$ & $\begin{array}{c}\text { Std. Error } \\
\text { of the } \\
\text { Estimate }\end{array}$ \\
\hline 1 &, $727 \mathrm{a}$ &, 528 &, 515 & 5,53677 \\
\hline
\end{tabular}

Table 4. Constanta and regression on each independent variables

\begin{tabular}{|c|c|c|c|c|c|}
\hline \multirow[t]{2}{*}{ Model } & \multicolumn{2}{|c|}{$\begin{array}{c}\text { Unstandardized } \\
\text { Coefficients }\end{array}$} & $\begin{array}{c}\text { Standar } \\
\text { dized }\end{array}$ & \multirow[t]{2}{*}{$\mathrm{t}$} & \multirow[t]{2}{*}{ Sig. } \\
\hline & B & $\begin{array}{l}\text { Std. } \\
\text { Error }\end{array}$ & Beta & & \\
\hline $\begin{array}{l}\text { (Consta } \\
\text { nt) }\end{array}$ & 8,867 & 4,628 & & $\begin{array}{r}1,91 \\
6\end{array}$ &, 057 \\
\hline (COG) & ,173 & ,042 & ,267 & $\begin{array}{r}4,13 \\
7\end{array}$ &, 000 \\
\hline (ICS) & ,008 & 042 & 012 & 190 &, 850 \\
\hline
\end{tabular}

\begin{tabular}{l|r|r|r|r|r|} 
(MMP &, 379 &, 048 &, 492 & 7,90 &, 000 \\
O) & & & & 6 & \\
$(\mathrm{ER})$ &, 185 &, 046 &, 241 & 3,99 & \\
& & & \\
\end{tabular}

Based on the output of calculation, it can be made several interpretations as follows. First, model of linear regression which estimated can be used to explain the effect of the four independent variables - CA, SM, ER, and IS on the PT (dependent variable) because the value of $\mathrm{F}$ arithmetic by 0,0000 is smaller than the 0.05 significance level. Similarly, the coefficient value determination $\left(\mathrm{R}^{2}\right)$ of 0.528 implies that the contribution of the regression equation to explain the PT diversity is $52.8 \%$ and the rest $(47,2 \%)$ is explained by another variables. Based on criteria of the feasibility model of Hair et al. [31] and Henseler, et al. [32], the magnitude of this contribution is sufficient. So the coefficient of determination $\left(\mathrm{R}^{2}\right)$ of $52.8 \%$ can be used to draw the conclusion that the conceptual model were proposed in this study is feasible to explain the PT. Second, the result calculation obtained regression equation $\mathrm{Y}=$ $8,867+0,173 \mathrm{CA}+0,008 \mathrm{IS}+0,379 \mathrm{SM}+0,185 \mathrm{ER}$ are in positive direction. These results explain that CA, SM, ER, and IS have a direct relationship with the PT. PT will increas if CA, SM, ER, and IS increase. Three, analysis partialy to test the influence of the CA, SM, ER, and IS singly on PT were obtained result that CA, SM, and ER give significant influence to PT, while IS gives no significant effect. This founding imply that SM gives the most influence on PT compared to the other three independent variables. Four, based on the overall analysis can be done modification of the relationship between variables as as illustrated in the following chart 2.

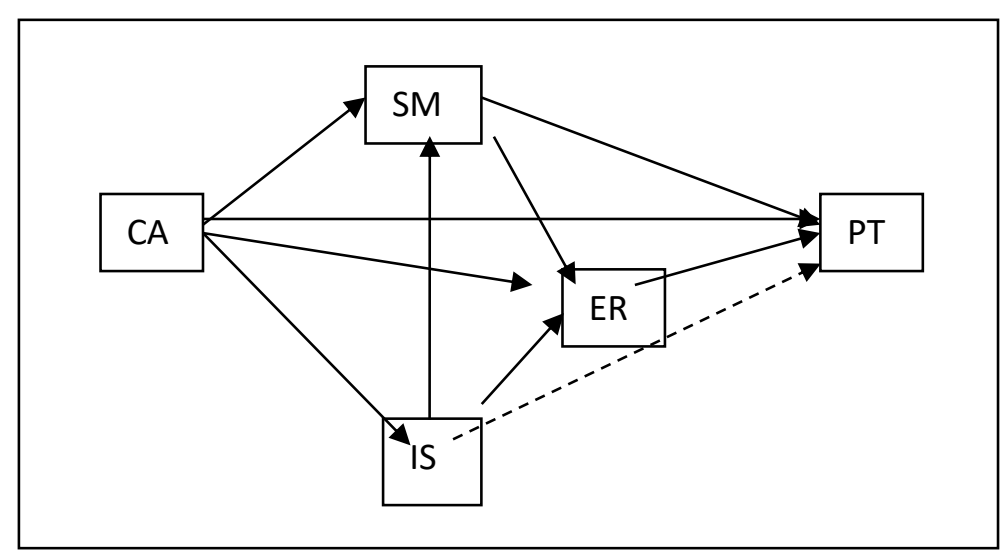

Chart 2. The empirical model of the relationship between the perspective talking (PT) with cognitive ability (CA), social motivation (SM), emotional regulation (ER), and interpersonal skills (IS) 


\section{CONCLUSIONS AND RECOMMENDATIONS}

Conclusion. Based on the results of the analysis, it can be concluded that the variables of cognitive ability (Cog), motivation (Mo), emotional regulation (ER), and interpersonal communication skills (ICS) can affect the perspective taking either jointly or individually. However, based on partial analysis found that from the four independent variables studied, the ICS variables have no significant effect. Although the Cog, Mo, and ER variables give effect to the perspective taking, based on the value of their determination coefficients, the effect is small except the motivation variable. Motivation gives the greatest impact compared to other variables.

Suggestion. The findings of this study appear to be less supportive of theoretical models of perspective taking because the contribution of each variable (factor) is small. In addition, the effect of ICS on perspective taking is not significant. However, these findings at least can explain that the motivation to the perspective of others contributes most powerful to the perspective taking. This corresponds to perspective taking theoretical model from Gehlbach [24], Parker et all. [25], and $\mathrm{Ku}$ et all. [26] which asserted that taking the perspective of others needs to be preceded by a tendency or propensity to engage in activities taking perspective from others. Without motivation to engage in activities taking perspective from others, accuracy of perspective taking will never happen. The implication from this study is that the school guidance and counseling programs intended to develop the perspective taking need to focus on developing learners 'motivation to take others' perspective.

\section{REFERENCES}

[1] H. Mool and A.N. Meltzoff, "Perspective-Taking and its Foundation in Joint Attention," In N. Eilan, H. Lerman, \& J. Roesler (eds.). Perception, causation, and Objectivity. Issues in Pshilosophy and Psychology, p. 286-304. Oxford, England: Oxford University Press, 2011.

[2] M.V. Fields, Learning Perspective Taking. Pearson Allyn Bacon Prentice Hall, 2010, [Online] Available: https://www.education.com. [Accessed: 27 July 2014].

[3] E. O'Brien, S.H. Konrath, D. Gruhn, and A.L. Hagen, "Empathic Concern and Perspective Taking: Linier anda Quadratic Effects of Sge Across the Adult Life Span.” The Journal of Gerontology, Series B: Psychological Sciences and Social Sciences, 2010.

[4] D.R. Shaffer, Social and Personality Development. Belmont, CA: Wadsworth Engage Learning, 2009.

[5] E. Galinsky, Mind The Making. The Seven Essential Life Skills Every Child Needs. New York: Harperstudio. An Imprint of HarperCollins Publisher, 2010.

[6] M.H. Davis, and A.T Martiner, "Perspective Taking and Intergroup helping." In S. Strummer and M. Snyder (Eds.), The Psychology of Prosocial behavior: group process, intergroup relations, and helping (h.175-190). Chichester, England: Wiley-Blacwell, 2010

[7] T.R. Goldstein, "Enhancing Empaty and Theory of Mind." Journal of Cognition and Development, 13 (1), 19-37. Boston College: Psychology Press, Taylor and Francis Group, 2012.

[8] L. Roan, B. Strong, P. Foss., M. Yager, H. Gehlbach, and K. Metcalf, Social Perspective Taking. Arlington: United States Army Research Institute, 2009
[9] N. Epley, E.M. Caruso, and M.H. Bazerman, "When Perspective Taking Increases Taking: Reactive egoism in Social Interaction." Journal of Personality and Social Psychology, Vol. 91, No.5, pp. 872889, 2006.

[10] S. Chadwick and E. Realston, "Perspective Taking in Structured and Unstructured Online Discussion." International Journal of teaching and Learning in Higher Education, Vol. 22, No. 1, 1-11, 2010.

[11] T. Elizabeth and R.L. Selman, "The Role Social Development in Elemntary School Curricula: Past, Present, and Future." [Online]. Available: Http://www. saperstainassocistes.com/ uploads/ 2015/2012_Elizabeth \& Selman_SD. [Accessed: 15 January 2015]

[12] N. Eplley, C.K. Morewedge, and B. Keysar, "Perspective Taking in Children and Adults: Equivalent Egocentrisme but Differential Correction." Journal of Experimental Social Psychology, 40, 760768, 2004. [Online) Avaliable: http://www. elsevier.com/locate/ jesp. [Accessed: 12 December 2014].

[13] E. Galinsky, Mind The Making. The Seven Essential Life Skills Every Child Needs. New York: Harperstudio. An Imprint of HarperCollins Publisher, 2010.

[14] H. Gehlbach, M.E. Brinkworth, and Ming-Te Wang, "The Social perspective Taking Process: What Motivates Individuals to Take Another's Perspective." Teacher College Record, Vol. 114, No. 1, 1029, 2012.

[15] J. Calderon, "Perspective-Taking as a Tool for Building Democratic Societies. Diversity and Democracy." Civic Learning for Shared Futures, Vol. 14, No. 1, 106-115, 2011.

[16] L.J. Linck, R.I., Wohlberg, and A.K. Salmon, "Creating a Culture of Thinking that Cultivate the Perspective-Taking Disposition," In Proceeding of the 11th. bAnnual College of Education \& GSN Research Conference (99-104). [Online] Miami: Florida International University, 2012. [Online]. Avaliable: http://education.fiu.idu/ research_conference/... [Accessed: 17 may 2015].

[17] R.L. Smith, "Social Perspective-Taking in The Friendships of Adolescents: Implications For Friendship Quality And Emotional Adjustment." A Thesis presented to the Faculty of the Graduate School at the University of Missouri - Columbia. [Online]. Available: https://mospace.umsystem.edu. [Accessed: 3 Januaryi 2016].

[18] C.P. Casanave, "Perspective Taking." In A.M. Stoke (Ed.), JALT2009 Conference Proceeding. Tokyo: JALT Publication, 2010.

[19] R. Trotchell, D.D, Loschelder, J. Huffmeier, and K. Schwartz, "Perspective Taking as means to Overcome Motivastional Barriers in Negotiations: When Putting Oneself into the Opponent's Shoes Helps to Walk toward Agreements." Journal of Personality and Social Pathology, 4, 771-790, 2011.

[20] C.L. Walker, B.M. Shore, and Tabatabai, "Eye of Beholder: Investigating the Interplay Between Inquiry Role Diversification and Social Perspective Taking." International Journal of Educational Psychology, 2 (2), 144-192, 2013. [Online]. Available: http://dx.doi.org/ 10.54471/ijep.2013.23. [Accessed: 27 May 2016].

[21] N. Eppley and A. Waytz, "Perspective Taking. In Harry T. Reis and Susan Sprecher." Encyclopedia of Human Relationships. Sage Publication, Inc., 2009. [Online] Available: Http://dx.doi.org./ 10.4135/... [Accessed: 15 December 2015].

[22] J. Kezuma, "Perspective Taking Skills." [Online] Avaliable: https://jillkezuma.wordpress.com. Perspective taking-skills/... [Accessed: 21 January 2014]

[23] R.S. Rubenstein, "Adolescent Social perspective Taking in Contexts of Social Justice: Examining Perceptions of Social Group Differences." Thesis. Thoronto: Departement of Human Development for Applied Psychology, Ontario Institute for Studies in Education, University of Toronto, 2012.

[24] H. Gehlbach, "A New Perspective on Perspective Taking: A Multidimentional Approach to Conceptualizing an Aptitude." Educational Psychology Review, Vol. 16, No. 3, pp. 207-234, $\begin{array}{llll}\text { September, } & 2004 . & \text { [Online] } & \text { Avaliable: }\end{array}$ http://dx.doi.org/10.1023/B:EDPR. 0000034021.12899 .11 [Accessed: 13 May 2015] 
[25] G, Ku, C.S. Wang, and A.D. Galinsky, "The Promise and Perversity of perspective Taking in Organizations." Research in Organizational Behavior, Vol. 35, 79-102, 2015. [Online]. Avaliable: http://www.lbsresearch.london.edu. [Accessed: 27 April 2016].

[26] A.K. Parker, P.W.B. Atkins, and C.Mm Axtell, "Building Better Work Place through Individual Perspective Taking: A Fresh Look at a Fundamental Human Process." International Review of Industrial and Organizational Psychology. Wiley, 2008. [Online]. Available: http://www. researchgate.net. [Accessed: 18 Nov. 2015].

[27] R.L. Selman, The growth of interpersonal understanding: Developmental and clinical analyses. New York: Academic Press, 1980
[28] N. Eppley, and E.M. Caruso, Perspective Taking: Misstepping Into Others' Shoes. Handbook of Imagination and Mental Simulation. (Markmond, K.D. et al. ed), 2008.

[29] D.E. Papalia and S.W. Olds, Human Development (sixth ed.). NY McGraw-Hill, Inc., 2008

[30] A. Atmoko, A. Model Tindakan Guru Menanggapi Perilaku Emosional Siswa dalam Pembelajaran Sekolah Dasar di Kota Malang. Disertation. Don`t Published.

[31] J.E.F. Hair, W.C. Black, B.J. Babin, and R.E Andersen, Multivariate Data Analysis. [Online]. Available: www//Blog.sciencenet.en>hair et al. [Accessed: 20 July 2017].

[32] J. Henseler, C.M. Ringle, and R.R. Sinkovics, "The Use of Partial Least Squares path Modeling in International Marketing." Advances in International Marketing, 20, 277-320, 2009. 